\title{
Day of judgement for intelligent design
}

\section{WASHINGTON DC}

Two states chalked up radically different results last week in local voting over the teaching of evolution in their schools. Darwin's theory was being pitted against intelligent design - the concept that an intelligent creator shaped the course of evolution. Evolution lost one battle and won the other.

On 8 November, the Kansas State Board of Education narrowly approved a set of standards for science teaching, backed by supporters of intelligent design, that highlight "gaps" in evolution theory. "I think this is a huge victory for students in Kansas," says Casey Luskin, a programme officer in policy and legal affairs at the Discovery Institute, an intelligent-design think-tank in Seattle, Washington.

On the same day, in Dover, Pennsylvania, district elections ousted eight of nine schoolboard members who support intelligent design. Last year, the board brought in a requirement that, at the start of biology lessons, teachers read pupils a statement criticizing evolution and endorsing intelligent design. A group of parents sued the school district over this, and a federal judge is now deliberating on the case (see Nature 437,$607 ; 2005$ ).

As science educators in Kansas and Pennsylvania respond to the situation (see 'Science advocates tackle fallout from school-board votes on evolution'), the election results underscore the highly decentralized nature of US education. Unlike most European countries, which set their curricula through a central education ministry, the United States has no established national standards, says Jay Labov, a senior adviser for education at the National

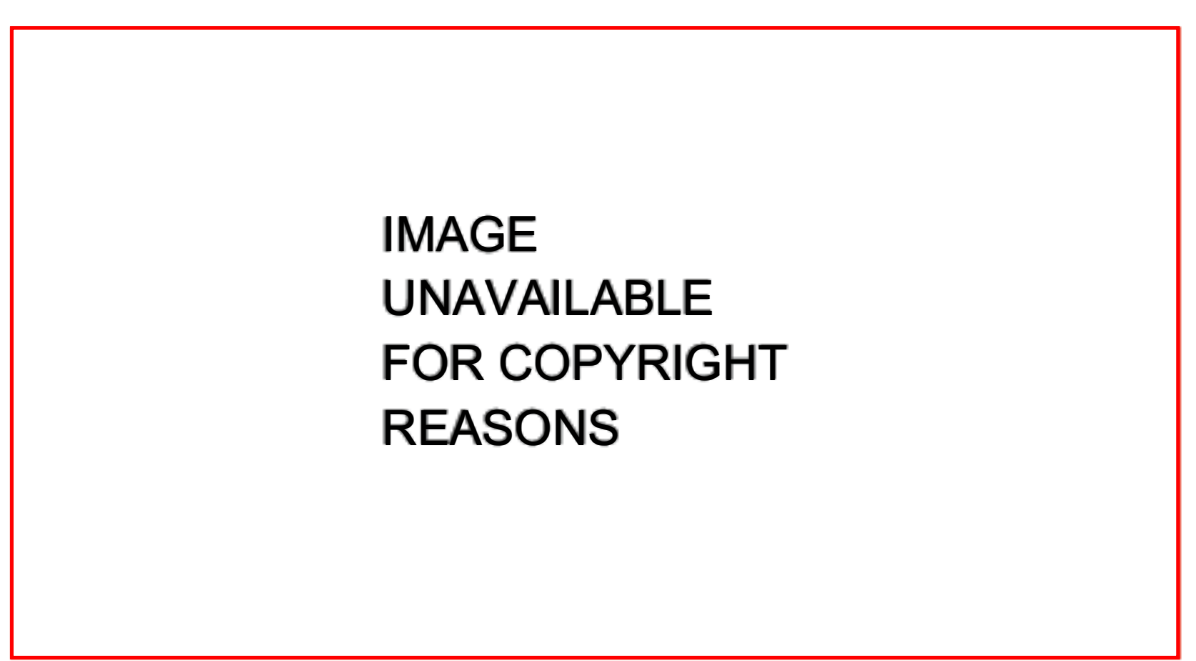

Eight members of Dover's school board lost their seats to supporters of the teaching of Darwin's theory.

Academies in Washington DC. Elected education boards set the standards in each state, and local school districts - each with their own elected board - determine how the standards are implemented in the classroom.

In the case of science, most states have voluntarily adopted a set of guidelines laid out by the National Academies in 1996. All but one of the 50 US states (Iowa) have adopted the standards wholly or in part, says Labov, and their 16,000 school districts decide how to teach them. ${ }^{\alpha}$ Under those circumstances you can imagine that such a document is treated in different ways," he says. Such was the case in Kansas, where the academies-approved guidelines were altered to open the door for intelligent design.
A recent analysis shows how differently the teaching of evolution is treated across the United States. Education Week, a national journal for teachers and educators, reported in its 9 November issue that most states mention evolution in their scientific standards, but surprisingly few specify key evolutionary concepts. Only 22 states mandate the teaching of mutation and natural selection, for example. Four states fail to mention evolution at all.

"It's disappointing but not surprising," says Wayne Carley, executive director of the National Association of Biology Teachers in Reston, Virginia. "We as science educators bear some of the responsibility for this." Geoff Brumfiel

\section{Science advocates tackle fallout from school-board votes on evolution}

In Kansas, Jack Krebs is getting ready for a fight. Krebs, a high-school maths teacher who is vice-president of Kansas Citizens for Science, fought hard against the sciencestandards adopted last week by the state education board. He fears that their approval will encourage local districts to move away from teaching evolution.

"This vote is going to open the door for anyone who's leaning towards creationism," Krebs says. Researchers and educators, he argues, must now focus on next year's board elections. If more science-friendly candidates are elected, the standards could be changed before they are implemented in 2007.

Meanwhile, in Pennsylvania, Bryan Rehm is working to patch up a divided community. Rehm is a high-school physics teacher and one of the parents who sued Dover's school board lastyear over its requirement for teachers to read out a disclaimer on evolution in biologyclasses. But now Rehm has been elected to the board as
IMAGE UNAVAILABLE FOR COPYRIGHT REASONS

Jack Krebs fears that Kansas schools may turnagainst teaching evolution. part of a coalition that promises to find a way forward.

The issue has split the small town of Dover. Two atheist cabletelevision shows have made sport of religious members of the community. Rehm, a practising Christian, has received dozens of angry e-mails from locals who support intelligent design. "What we need to do in Dover is have a conversation about science, religion and whether there is a conflict between the two," he says.

The newboard is considering introducing a comparative religion course that would discuss, among other things, intelligentdesign. G.B. 